\title{
Cape Verde (West Africa) Successful Water Reuse Pilot Project: A Sustainable Way for Increasing Food Production in a Climate Change Scenario
}

\author{
Vanessa Mendoza-Grimón ${ }^{1,+}+\mathbb{D}$, Juan Ramón Fernández-Vera ${ }^{2}$, Gilbert Duarte Silva ${ }^{3}$, Angelo Semedo-Varela 4 \\ and María del Pino Palacios-Díaz ${ }^{1, *,+}$ (D) \\ 1 Instituto de Investigación IUNAT, Grupo GEOVOL, Universidad de Las Palmas de Gran Canaria, \\ 35001 Las Palmas de Gran Canaria, Spain; v.mendozagrimon@ulpgc.es \\ 2 Laboratorio Agroalimentario y Fitopatológico del Cabildo de Gran Canaria, 35013 Arucas, Spain; \\ jrfernandezv@grancanaria.com \\ 3 Instituto Nacional de Investigação e Desenvolvimento Agrário (INIDA), 84 São Jorge dos Órgãos, Cape Verde; \\ gilbert.silva@inida.gov.cv \\ 4 INDUS, Instalações Gerais e Manutenção Lda-Praia, Rua Santa Luzia-Palmarejo, 7601 Praia, Cape Verde; \\ indusgestcv@gmail.com \\ * Correspondence: mp.palaciosdiaz@ulpgc.es; Tel.: +34-928-454-353; Fax: +35-928-451-142 \\ + These authors contributed equally to this work.
}

check for updates

Citation: Mendoza-Grimón, V.; Fernández-Vera, J.R.; Silva, G.D.; Semedo-Varela, A.; Palacios-Díaz, M.d.P. Cape Verde (West Africa) Successful Water Reuse Pilot Project: A Sustainable Way for Increasing Food Production in a Climate Change Scenario. Water 2021, 13, 160. https://doi.org/10.3390/w13020160

Received: 15 August 2020 Accepted: 9 January 2021 Published: 12 January 2021

Publisher's Note: MDPI stays neutral with regard to jurisdictional clai$\mathrm{ms}$ in published maps and institutional affiliations.

Copyright: (C) 2021 by the authors. Licensee MDPI, Basel, Switzerland. This article is an open access article distributed under the terms and conditions of the Creative Commons Attribution (CC BY) license (https:// creativecommons.org/licenses/by/ $4.0 /)$.

\begin{abstract}
Cape Verde, which has agricultural land that is mainly rainfed, will be severely affected by climate change due to increased drought conditions. Scarce water availability makes this country highly dependent on imports for its food supply, resulting in more than $80 \%$ food importation. Improving water use efficiency, implementing precision irrigation could help achieve sustainable use of water resources. Cereal production reusing treated water could contribute to strengthening resilience and adaptation to climate change in Cape Verde. Our pilot project demonstrates that the safe and profitable reuse of water produced by Cape Verde's water treatment plants is possible by avoiding water and plant contact using Subsurface Drip Irrigation (SDI), obtaining food yields between 10,000 and $7000 \mathrm{~kg}$ of $\mathrm{cob} / \mathrm{ha}$, with a water consumption of about $300 \mathrm{~L} / \mathrm{kg}$ Dry-Matter and a Water-Use-Efficiency of about $3 \mathrm{~g} / \mathrm{L}$. These studies also showed that it is necessary to provide training to farmers and to conduct further studies to help solve present challenges. This project identif installation failures as water shortages can compromise farmers' profitability. To guarantee the sustainability of water reuse, it is also necessary to consider economic and social factors, including that all water that is not reused is poured, increasing environmental and sanitary risk and decreasing the possibility of recovering water treatment costs.
\end{abstract}

Keywords: SDI; treated water reuse; WUE; water management; precision irrigation; cereal production; food sovereign

\section{Introduction}

Countries with rain-dependent agriculture will be the most affected by trends in climate change due to drought increases. In this regard, water scarcity is the main factor affecting agriculture and is strongly influenced by weather and climate. One of these countries is Cape Verde, which lies in the sub-Saharan African climatic zone and is considered by the World Bank as a lower middle-income country [1]. Cape Verde presents a wet season of one to three months, with a potential evaporation exceeding precipitation throughout the year (annual precipitation ranges from $80-300 \mathrm{~mm}$ in the arid coastal zones to $1200-1600 \mathrm{~mm}$ in the highlands of the mountain islands) [2], average annual temperatures are usually moderate, around $25^{\circ} \mathrm{C}$, due to maritime influence, with the highest monthly average temperatures in September (warmest season, $26.7^{\circ} \mathrm{C}$ ) and the lowest in 
the cool season (January-February, $18.4{ }^{\circ} \mathrm{C}$ ) [3]. Prolonged droughts over the past decades is one of the most important problems in Cape Verde for crop production and food supply

As described in the Climate Change Knowledge Portal in Cape Verde, the trend towards more consecutive dry days and higher temperatures [4] will increase evaporation and add stress to limited water resources, affecting irrigation and other water uses. In general, the average annual maximum number of consecutive dry days is projected to increase for the higher emissions scenarios considered by IPCC. Following one of these, RCP 2.6 scenario, mentioned the study estimates that median values of 231, 223 and 242 consecutive dry days could be expected in Cape Verde, in 2030, 2050 and 2080, respectively.

Only $10 \%$ of Cape Verde's territory is classified as arable land [4]. Its farming, pastoralism and forestry are highly vulnerable because of poor natural resources, an arid climate and the prevalence of traditional low intensive farming systems [5]. Due to water scarcity, the agricultural production is based traditionally on the rain-fed system. Only 2085 hectares are irrigated of the total agricultural area (79,000 ha), representing 2.64\% [6]. Production estimates of fruit in Cape Verde (2016) are 10443, 3283 and 1363 tons for banana, papaya and mango, respectively [7]. Santiago Island has the largest area used for agriculture (52\%) [3]. The main irrigated crops are Sugarcane (1000 ha) with $48 \%$, vegetables ( $880 \mathrm{ha}$ ) with $42 \%$ and potatoes and other tubers (210 has) with 10\% irrigated area. Irrigated sugarcane is implemented all year, vegetables are cultivated from April to August and tubers from November to May [8]. Corn (Zea mays) grown under the rainfed system resulted in yields of 5642 tons in 2016 [7] and 5314 in 2017 [1]. The production remains stable in 32,000 ha since 2010, with a mean yield of about $2000 \mathrm{~kg} / \mathrm{ha}$ [8].

In Cape Verde, Agricultural water withdrawal represents $91 \%$ of total water withdrawal, while municipal, and industrial only represents $7 \%$ and $2 \%$, respectively [9]. According to water demands estimates in Santiago Island for the year 2030, about $48,375 \mathrm{~m}^{3} /$ day will be needed for agriculture [10]. Ground water levels are lowering and mare intrusion is high, reducing the groundwater quality and availability. Consequently, agro-climatic conditions and low water availability make this country heavily dependent on imports for food supplies. In fact, Cape Verde imports more than $80 \%$ of the food needs [11]. In this context, non-conventional water resources are one the alternatives to alleviate the hydrological imbalance between water consumption and renewable resource availability [12]. Providing water for irrigating these resources allows for decreasing imports of food supplies. In this water scarcity context $(228 \mathrm{~mm}$ year of long term average annual precipitation [9]), a gain or a decrease over the coming decades could determine if certain crops or farm practices remain viable, and if reduced water availability might require a shift to more drought resistant crops or if farmers are required to shift investments into irrigation [4]. Therefore, as sustainable use of water resources is needed, it is necessary to improve irrigation water-use efficiency (WUE) and precision irrigation scheduling is a good tool to address this challenge. Previous works of Zea mays sprinkle irrigation have demonstrated that below an $8 \%$ slope, the soil and crop characteristics had an overriding influence on soil moisture (highly variable), and this influence increased during the growing season [13]. In spite of that, using subsurface drip irrigation (SDI) technology, roots can easily extract water from the subsurface, which remains constantly wet, while the soil moisture content at the top can remain dry (decreasing evaporation losses). This water management can save water for about $25 \%$ [14].

In this context, reclaimed water irrigation in cereal production could contribute significantly to strengthening resilience and adapting to climate change capabilities in Cape Verde, and enhancing the adaptive capacity to address the additional risks to desertification and land degradation. To ensure sanitary safety when reusing treated water, SDI is the best option because SDI demands a lower level of water treatment than any other alternative [15], improves health security by preventing the contact between water and stems and leaves, and thus, minimizing sanitary risk. SDI has other advantages, including water-conservation practices and easy mechanization of high yielding crops [16]. Besides, SDI uses the soil as a natural advanced (but not high cost) water treatment, the in situ 
reuse of RW produced by low-tech wastewater plants would provide a valuable resource for small rural villages [17]. Currently, in Santiago island, there are five wastewater treatment plants (WWTP), one of these is Santa Catarina WWTP with a treatment capacity of $225 \mathrm{~m}^{3}$ /day [18], of which $144 \mathrm{~m}^{3} /$ day are actually treated [7]. In this situation, the proposed reuse of treated water for irrigation increases water resources available to agricultural production, decreases the needs of conventional water, avoids uncontrolled water pouring and allows for the recovering of part of the water treatment costs.

Besides water scarcity, the Cape Verde farmers have a new insect pest problem, Spodoptera frugiperda, which cause severe economic damage in various crops such as maize, sorghum, beans and cotton $[19,20]$.

The objective of this study is to determine the effects of reclaimed water irrigation technology in the production of corn under in agro-climatic conditions in West Africa (Cape Verde). Specific objectives include the determination of the effects of water quality in irrigation systems (guidelines of installation and proper maintenance) and water management and consumption on corn production. In addition, to determine the environmental effects on soil evolution and water drainage potential, there is a sustainable way for increasing food production. Further studies will present economic and social considerations.

\section{Materials and Methods}

\subsection{Experimental Plot}

The experimental plot is localized in Achada Galego ( $15^{\circ} 5^{\prime} 50.93^{\prime \prime} \mathrm{N} ; 23^{\circ} 41^{\prime} 02.73^{\prime \prime} \mathrm{W}$, $433 \mathrm{~m}$ a.s.l.), Santa Catarina (Santiago island, Cape Verde). The area has a warm, humid and sunny climate, with a mean of minimum temperatures $(\mathrm{Tm}): 21.4{ }^{\circ} \mathrm{C}$, mean of maximum temperatures (TM): $28.9^{\circ} \mathrm{C}$, mean humidity: $70 \%$ and $7.2 \mathrm{~h}$ of sun. Therefore, it has a high ET mean reference evapotranspiration of $5.44 \mathrm{~mm}$ (between 4.46 in August and 6.84 in April, Figure 1).

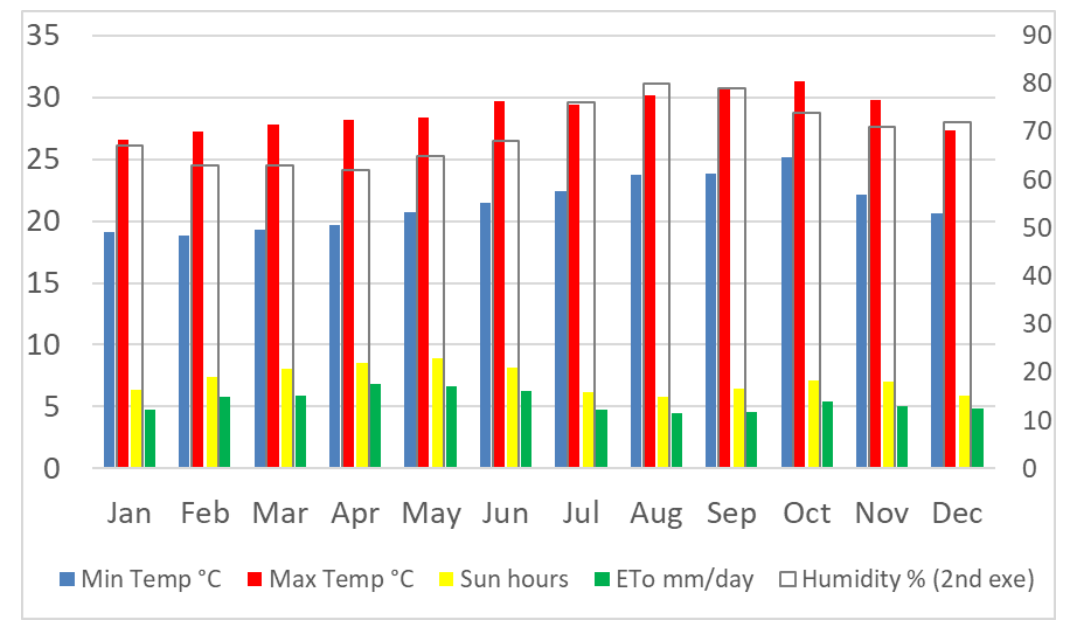

Figure 1. Monthly minimum temperatures (Tm), maximum temperatures (TM), reference evapotranspiration, humidity and hours of sun. Data from Automatic weather station $-23.51^{\circ} \mathrm{N} 14.9^{\circ} \mathrm{W}, 27 \mathrm{~m}$ a.s.l. Praia, FAO, 2020. AQUASTAT (CLIMWAT 2.0 FAO).

After preliminary works, consisting of the removing stones and ploughing in $600 \mathrm{~kg}$ of manure, Zea mays was seeded twice in an experimental plot of $480 \mathrm{~m}^{2}$, in 2019 and 2020. The traditional rainfed-seeding mode: holes spaced $0.5 \mathrm{~m}$ with 4 seeds per hole, was used in 2019. In 2020, one seed per hole was sowed, coinciding with the buried drip lines. Each hole was buried at a distance of approximately 0.2 per meter, giving a higher plant density than was used in 2019. Two harvests were obtained: a first productive period of 96 days (from 23 April 2019 to 20 July 2019) and a second period of 100 days (17 February to 27 May 2020). In both periods, the rainfall was $0 \mathrm{~mm}$. 
The plot was divided in three areas based on water availability: rainfed $\left(60 \mathrm{~m}^{2}\right)$, support irrigation $\left(60 \mathrm{~m}^{2}\right)$ and subsurface drip irrigation (SDI, $\left.360 \mathrm{~m}^{2}\right)$. The SDI area was divided into three blocks. Both of the two treatments were irrigated in each block (6 subplots). Each subplot consists of 8 lines of $10 \mathrm{~m}$ long (see Supplementary Figure S1, left).

Two estimations of water consumption, one for 2019 and the other for 2020, were calculated using CROPWAT, a FAO computer program for irrigation planning and management [21]: $5164 \mathrm{~m}^{3} / \mathrm{ha}(2019)$ and $6375 \mathrm{~m}^{3} / \mathrm{ha}$ (2020). Two irrigation treatments were used, consisting of irrigation with approximately: $80 \%$ (T1) and $60 \%$ (T2) of the estimation of water consumption in 2019, and 110 (T1) and 100\% (T2) of the estimation of water consumption in 2020. Besides, and as local evapotranspiration data were not available (data used by CROPWAT are from Praia, located in the Southern coast), 12 soil moisture and temperature sensors (6 in T1 and 6 in T2) were installed in the experimental field, $0.1 \mathrm{~m}$ apart from the irrigation lines ( 3 at the surface and 3 buried at $0.2 \mathrm{~m}$ ) to monitor soil water status (see Supplementary Figure S1, right). The electromagnetic SM300 sensors determine volumetric soil water content $(\theta)$ in a sampling volume of $0.1 \mathrm{~L}$, by measuring soil dielectric permittivity $(\varepsilon)$ with a $100 \mathrm{MHz}$ wave-form, having an accuracy of $\pm 2.5 \%$ vol and a salinity error $<3.5 \%$ vol below $1 \mathrm{dS} / \mathrm{m}$ [22]. Water dosage was determined in order to maintain soil surface dry, while the subsurface soil was wet.

In this sense, in January 2019, when the sensors were installed prior to seeding, the soil was very dry (Figure 2A). As shown in Figure 2B, soil moisture during the growth period remaining stable between 16\% (dry at the soil surface) and 36\% (close to field capacity), depending on soil position.

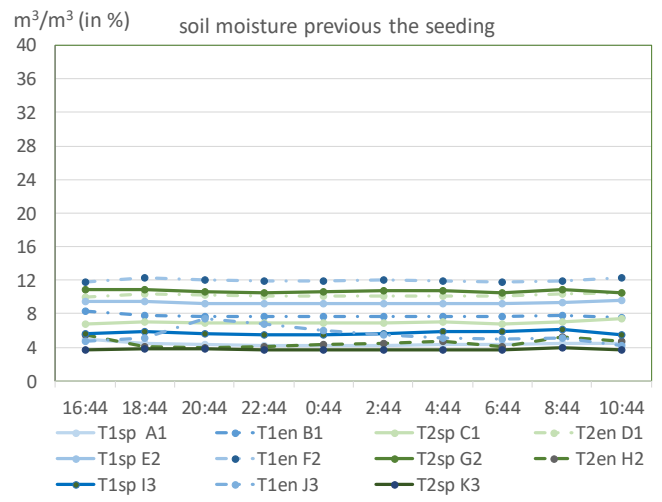

(A)

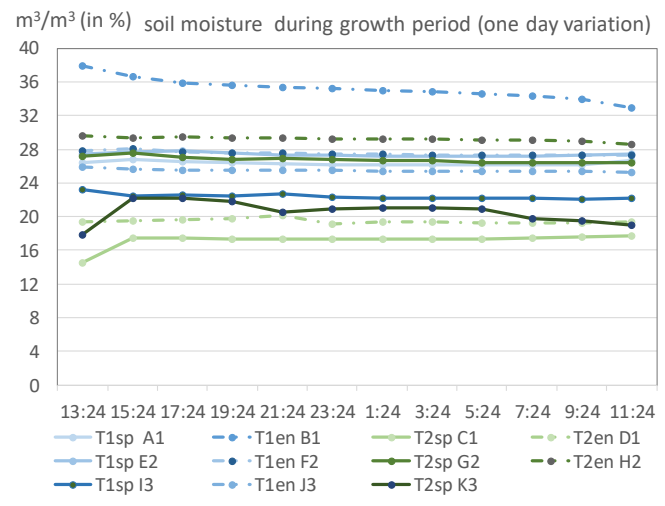

(B)

Figure 2. One-day data of soil moisture measured every two hours using the soil electromagnetic sensors, prior to the seeding (A) and during the growth period (B).

\subsection{Irrigation System}

An irrigation head consisted on one controller, one pump, one sand filtration system and a UV disinfection lamp was installed to apply the reclaimed water by the subsurface drip irrigation (SDI) system (see Supplementary Figure S2). Integral drippers: pressurecompensating at range 1.5-4.0 bar, anti-siphon and high anti-drain mechanism spaced $0.5 \mathrm{~m}$ with delivery rates at $2.3 \mathrm{~L} / \mathrm{h}$ were used. The lateral lines were spaced at $0.75 \mathrm{~m}$ and buried at $0.20 \mathrm{~m}$ depth. Irrigation was provided daily, two times a day. Each treatment had a flow meter. Proper maintenance was used during the irrigation period: a washing treatment of the sand filter was programed by 2 min twice a week, and also, drip irrigation lines were washed twice a month.

In $2019,4.1 \mathrm{~L} / \mathrm{m}^{2}$ and $3.1 \mathrm{~L} / \mathrm{m}^{2}$ (T1 and $\mathrm{T} 2$ respectively) were applied during 45 days (from seeding to development period) and $5.1 \mathrm{~L} / \mathrm{m}^{2}$ and $4.1 \mathrm{~L} / \mathrm{m}^{2}$ during the mid and late season. The water consumption of the whole period was 4242 and $3261 \mathrm{~m}^{3} / \mathrm{ha}$ (T1 and T2 respectively) were used, representing $18 \%$ and $37 \%$ less water than calculated using 
CROPWAT [21]. Therefore, in 2019, T2 used 23\% less water than T1. In 2020, due to the higher plant density and the lower seed depth used, and in order to provide the soil, a proper water status guaranteeing nascence, $12.3 \mathrm{~L} / \mathrm{m}^{2}$ were applied for both treatments during 28 days. After that, $5.1 \mathrm{~L} / \mathrm{m}^{2}$ and $4.1 \mathrm{~L} / \mathrm{m}^{2}$ (T1 and T2, respectively) were applied for 45 days. Then, during the Covid-19 confinement period, a power outage of 14 days was produced, causing irrigation failure (see supplementary Figure S3). Once the power was recovered, $61 \mathrm{~L} / \mathrm{m}^{2}$ was applied during 4 days to rewet the soil. After that, and until harvest, 6.1 and $4.1 \mathrm{~L} / \mathrm{m}^{2}$ were applied per day. Water consumption to the whole period was: 6961 and $6297 \mathrm{~m}^{3}$ /ha (T1 and T2, respectively, with $10 \%$ less water than T1), representing $9 \%$ more and $2 \%$ less water than calculated using CROPWAT.

\subsection{Water Quality}

The low energy treatment plant supplies water for this experiment. This plant, consisting of a secondary treatment, plus a naturally aerobic lagoon, treats $144 \mathrm{~m}^{3}$ per day [7]. Characterization of treated water after the pond made by INLAB (May 2019) is shown in Table 1. In order to quantify the risk of drippers clogging due to the algae growth in the pond, in January 2019, a sample was taken before entering the pond and after the sand filtration made by the irrigation head (Table 1), and suspended solids were measured in ULPGC Agronomy laboratory.

Table 1. Some chemical parameters of treated water after the pond (May 2019), and total suspended solids (SST) before entering the pond, in the pond and after sand filtration (January 2019).

\begin{tabular}{|c|c|c|c|c|c|c|c|c|c|c|c|c|c|c|c|c|}
\hline \multirow[t]{2}{*}{ Date } & \multicolumn{13}{|c|}{ Pond } & $\begin{array}{l}\text { Pre- } \\
\text { Pond }\end{array}$ & Pond & $\begin{array}{l}\text { Post- } \\
\text { Filtered }\end{array}$ \\
\hline & & $\mathrm{dS} / \mathrm{m}$ & & mg & & & & & & & & & & & $\mathrm{mg} / \mathrm{L}$ & \\
\hline \multirow[t]{2}{*}{$\begin{array}{l}\text { May } \\
2019\end{array}$} & $\mathrm{pH}$ & EC & COD & BOD $_{5}$ & Ntot & $\mathrm{NO}_{3}{ }^{-}$ & SAR & Ptot & $\mathrm{Cl}^{-}$ & $\mathrm{Na}^{+}$ & $\mathrm{K}^{+}$ & $\mathrm{Ca}^{2+}$ & $\mathrm{Mg}^{2+}$ & & SST & \\
\hline & 8.2 & 2.96 & 212 & 60 & 130 & 232 & 10 & 37 & 580 & 434 & 96 & 69 & 45 & 72 & 250 & 154.7 \\
\hline
\end{tabular}

\subsection{Soil Analysis}

Samples of the Entisol soil were taken from the first $0.2 \mathrm{~m}$, prior to manure application (May 2017), and in 2019, coinciding with the seeding date (April 2019) and harvest (July 2019). The samples were taken from both treatments and from support irrigation and rainfed subplots. Due to the problems with samples transport (border closing), no data are available in 2020. Texture was determined by the Bouyoucos method. Organic carbon $(\mathrm{OC}, \%)$ and nitrogen $(\mathrm{N}, \%)$ were determined by dry combustion with a LECO CNS 2000 analyzer. Soluble salts were estimated by the electrical conductivity EC1:5 (soil:water ratio; $\mathrm{dS} / \mathrm{m}$ ). Available nitrate was determined by the extraction of soil, also at a 1:5 ratio, with $0.01 \mathrm{M}$ calcium chloride, and analyzed by ionic chromatography. Available soil P $(\mathrm{mg} / \mathrm{kg})$ was determined by sodium bicarbonate extraction, according to the Olsen method [23]. Exchangeable cations ( $\mathrm{K}, \mathrm{Ca}, \mathrm{Mg}$, and $\mathrm{Na}$, meq $100 \mathrm{~g}^{-1}$; $\mathrm{B}, \mathrm{Fe}, \mathrm{Cu}, \mathrm{Mn}$ and $\mathrm{Zn}, \mathrm{mg} / \mathrm{kg}$ ) were extracted with buffered $1 \mathrm{M}$ ammonium acetate at $\mathrm{pH}$ 7, and were analyzed by ICP. All the parameters were determined in Laboratorio Agroalimentario del Cabildo de Gran Canaria.

\subsection{Plant Characterization}

A Spodoptera frugiperda attack caused important losses in plant leaves and even more in cobs (see supplementary Figure S4). Samples of plants (considering only leaves and stem) from one meter of three centerlines for each subplot were weighed in the field, and then submitted to the lab. Fresh yield was transformed to be expressed in equivalent $\mathrm{kg} / \mathrm{ha}$. Additionally, excluding borderlines, all of the cobs of each subplot were classified in three qualities: 1: high, 2: medium and 3: low (without, poor/moderate and high pest attack, respectively). 
Composite samples of plants from T1 and T2 were taken in 2019 and 2020 to determine macro and microelements. Due to problems with sample transport (border closing), no data are available in 2020. Plant samples were subjected to microwave digestion with nitric acid. The following elements were analyzed by inductively coupled plasma optical emission spectrometry (ICP-OES): $\mathrm{P}, \mathrm{K}, \mathrm{Ca}, \mathrm{Mg}$, Na (expressed in \%), B, Cu, Fe, Mn and $\mathrm{Zn}$ (expressed in $\mathrm{mg} / \mathrm{kg}$ ). Nitrogen was determined by dry combustion in an LECO CNS 2000. All the parameters were determined in Laboratorio Agroalimentario del Cabildo de Gran Canaria.

\subsection{Statistical Analysis}

Analyses of variance, MANOVA for soil parameters and ANOVA for plant productivity parameters were carried out using statistical Packaged SPSS (version 26) by the Generalized Linear Model. For the soil parameters, the model included the treatment, date and their interactions. For plant yield (fresh weight), the model includes date (2019 and 2020), irrigation doses (T1 and T2), and their interactions. The same variables plus quality were used to characterize cob production. Mean separation was tested using the least significant difference (LSD), considering $p=0.05$. Additionally, cob quality is expressed in $\%$ weight of each class with respect to the total weigh for each treatment and date.

\section{Results and Discussion}

\subsection{Water Quality Effect on Irrigation System and Environment}

In spite of the high solid suspended values measured in the treated (increased in the mature lagoon) and sand filtered water (Table 1), due to the proper irrigation system maintenance, no clogging effects were observed in the irrigation system. This result coincides with those previously described by the authors in Reference [17], who avoided clogging in an SDI plot using a secondary effluent from 2002 to 2005, mentioning the importance of SDI maintenance practices.

Using the AQUASTAT climate information tool [24] implemented with the experimental data, 0 recharge and 0 drainage for 2019 and 2020 were estimated. Therefore, using adequate water dosage, no groundwater affection was caused by reclaimed water irrigation, which can be expected. This result must be considered regarding the environmental sustainability of treated water reuse.

\subsection{Soil Evolution}

Soil textural class was clay loam with values of sand, silt and clay were $24.3 \%, 43.3 \%$ and $32.4 \%$, respectively.

Table 2 shows the results of soil samples for each treatment before irrigation system installation: April 2019 (after manure application and coinciding with seeding) and July 2019, at harvest time.

Some soil parameters were significantly increased by time: EC, OM, C/N ratio, Nitrate, $\mathrm{Na}$ and $\mathrm{B}$ at 0.05 level and Ntot and Mn at 0.1 level. While not significant, soil available $\mathrm{P}$ is also shown as a tendency increased by time. Comparing data from treatments before and after being irrigated with reclaimed water (T1 and T2, between April and July 2019), $\mathrm{Mg}$ and $\mathrm{Cu}$ increased significantly, although $\mathrm{B}$ and $\mathrm{Mn}$ were not significantly different. However, no differences among parameters were observed in the treatments. Therefore, the observed increment in soil salinity cannot be assumed to be caused only by the use of treated water because non-irrigated treatment (T4) also increased its salinity. Further, no differences between T1 and T2 were observed, although T2 used 20\% less water. Previous studies have demonstrated that SDI increases soil salinity mainly at the surface [25]. Due to this fact, it is necessary to monitor soil salinity when using SDI and treated water in arid zones with high evapotranspiration rates (although data from 2020 are not available). In this sense and to avoid an unsustainable increment of top soil salinity, excess of irrigation during the rain period or an additional irrigation system have to be used to maintain the adequate salinity level tolerated by each crop, as SDIs do not allow lixiviate in the top soil. 
Table 2. Determination of soil $\mathrm{pH}$, electrical conductivity 1:5 (EC, dS/m), organic matter (OM, expressed in \%), total nitrogen ( $\mathrm{N}$ tot, expressed in \%), $\mathrm{C} / \mathrm{N}$ ratio, nitrate (expressed in $\mathrm{mg} / \mathrm{kg}$, available phosphorus (P, expressed in $\mathrm{mg} / \mathrm{kg}$ ), extracted cations (expressed as meq/100 g): potassium (K), calcium (Ca), magnesium (Mg), sodium (Na), and the rest of analyzed nutrients (expressed in $\mathrm{mg} / \mathrm{kg}$ ): boron (B), copper $(\mathrm{Cu})$, iron (Fe), manganese (Mn) and zinc (Zn), full irrigation (T1) and less water than T1 (T2), support irrigation (T3) and rainfed (T4), expressed by mean and standard deviation (when available).

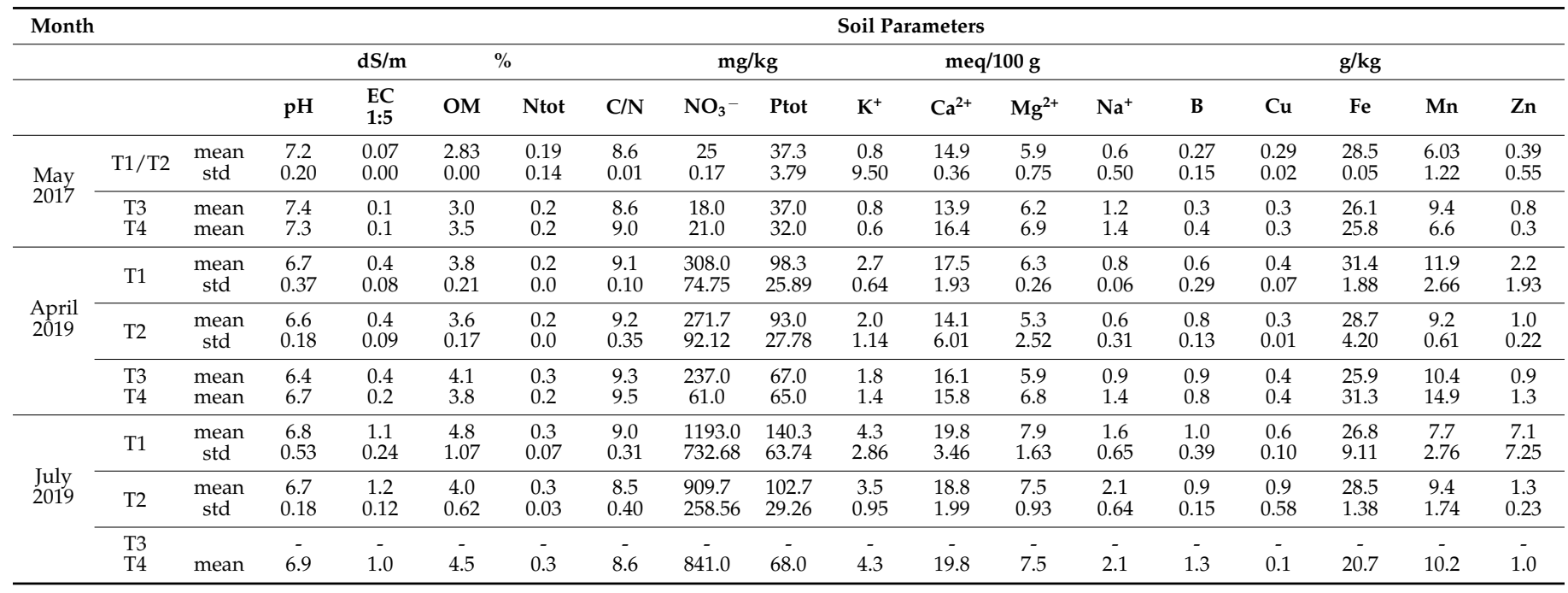

Manure application significantly increased $\mathrm{OM}, \mathrm{N}$ tot and $\mathrm{C} / \mathrm{N}$ ratio in the whole experimental field. During 2019, the observed OM and Ntot increment continued, which is probably caused by the increment in soil biological activity due to the root growth in T1 and T2. Tree roots growing close to the T4 plot could explain the $\mathrm{OM}$ and $\mathrm{C} / \mathrm{N}$ increasing in this plot (see supplementary Figure S1).

The notable increment of nitrate observed in April 2019 was possible due to the manure application and probably differed due to the rate of mineralization between water received in the soils (increment of $1200 \%, 1086 \%$ and $1316 \%$ for T1, T2 and T3, respectively) and soil without irrigation (290\%, T4). From April to July, less nitrate increment (387\% and $334 \%$ for $\mathrm{T} 1$ and $\mathrm{T} 2$ ) was observed in plots already mineralized (high mineralization ratio in the previous period) and higher increment (1378\% for T4) for the plot with a lower initial mineralization ratio. In spite of the treated water additions of $\mathrm{N}$ to soils of $\mathrm{T} 1$ and $\mathrm{T} 2$, nitrate values at harvest time showed no differences among treatments (T1, T2 and T4). This fact could be due to the equilibrium between $\mathrm{N}$ addition by treated water and its root absorption in T1 and T2 irrigated plots, as compared to T4, which had no $\mathrm{N}$ addition by treated water and no absorption by the roots (plants were not able to grow on this plot).

\subsection{Plant Yield}

Fresh plant weight was not significantly different between 2019 and 2020 harvests (July 2019 and May 2020), in spite of a power outage of about 14 days in which no water was applied during the Covid-19 confinement period (first of May 2020). Supplementary Figure S3 shows an image just before and after the power outage of approximately 14 days in which plants were not irrigated. The data in the 2020 harvest are consistent with the moment in which the plants were without irrigation, coinciding with the critical stage of water requirements (grain filling), but with leaves and stems growth already finished. As expected, the T1 yield was significantly higher, but not the 0.1 level than T2 (Figure 3). T2 used 23\% less water than $\mathrm{T} 1$ and $37 \%$ than the water needs estimated using CROPWAT. Depending on the water cost, T1 water dosage (14\% and 21\% higher weight than T2 in 2019 and 2020, respectively) would be profitable or not. No differences were shown between the date and treatment interaction. 


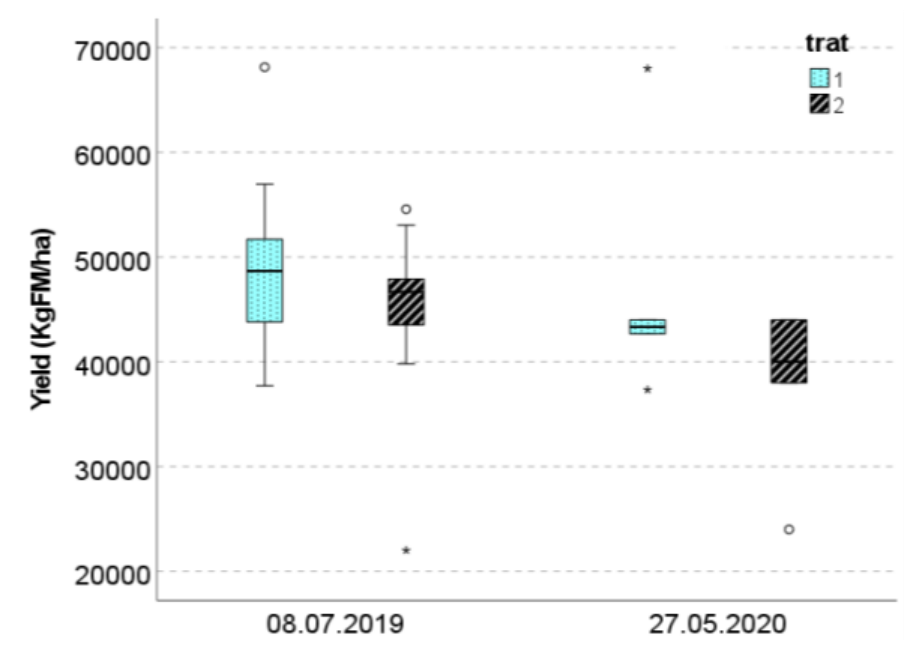

Figure 3. Box plot of fresh plant weight showing the effects of date (2019 and 2020, not significantly different) and treatment (T1 > T2 at $p=0.1$ level).

The results demonstrated that, at $422 \mathrm{~m}$ a.s.l., Cabo Verde has enough temperature to seed Zea mays in late winter (mid-February), when less crops are irrigated (vegetables are seeded in April) and lower ET0 is obtained. Irrespective of that, due to the problems experimented with in the irrigation management in 2020, a proper estimation of water consumption and plant yield was not possible. Further works have to be conducted in order to properly determine the mentioned data.

Crop establishment in dry regions is one of the SDI challenges [26]. In this sense, in 2020, the crop was seeded using the same plant density and depth used by mechanical machinery in high productivity sprinkler irrigated fields. A good crop establishment was achieved just after increasing water dosage during the first month to feed the seeds placed in the top-soil. Further works must be conducted to optimize water dosage during this period.

Regarding cob production, variables date, treatment and their interactions were significantly different (data are presented in Table 3). Additionally, the quality and date quality were significantly different, but not the rest of the quality interactions

Table 3. Cob production data (expressed as $\mathrm{kg}$ of cob/ha) for 2019 and 2020 harvest, T1 and T2 treatments and three qualities: 1: high, 2: medium and 3: low (without, poor/moderate and high pest attack, respectively).

\begin{tabular}{|c|c|c|c|c|}
\hline Date & Trat & Quality & Mean & Std. Deviation \\
\hline \multirow{6}{*}{ July 2019} & \multirow{3}{*}{1} & 1 & 1918.5 & 588.94 \\
\hline & & 2 & 2829.63 & 795.43 \\
\hline & & 3 & 5481.47 & 395.22 \\
\hline & \multirow{3}{*}{2} & 1 & 1414.83 & 383.21 \\
\hline & & 2 & 1511.1 & 293.94 \\
\hline & & 3 & 3977.8 & 167.81 \\
\hline \multirow{6}{*}{ May 2020} & \multirow{3}{*}{1} & 1 & 1177.77 & 635.96 \\
\hline & & 2 & 2577.8 & 613.84 \\
\hline & & 3 & 1533.33 & 308.73 \\
\hline & \multirow{3}{*}{2} & 1 & 829.63 & 244.77 \\
\hline & & 2 & 2385.2 & 859.62 \\
\hline & & 3 & 1651.83 & 453.99 \\
\hline
\end{tabular}

Irrigation system failure in 2020 during the filling grain period produced a reduction from $38.6 \%, 8.9 \%$ and $72.0 \%$ cob weight of each class of quality, compared to that obtained in 2019. The ratio of cob/total plant weight were calculated in both 2019 and 2020 (Figure 4), 
demonstrating a high decrease of this ratio from $20 \%$ (2019) to $10 \%$ (2020). Therefore, it is possible to point out that even a higher cob yield would be expected in 2020 than in 2019 if water shortage had not been produced. Data from 2020 demonstrates that, if water shortage coincides with the mentioned period, in spite of a later increment in water availability, cob weight cannot be recovered. Therefore, a proper maintenance of water treatment installations must be able to provide farmers enough irrigation water, especially in critical moments. Additionally, having storage ponds will allow for a decrease of risks of water shortage and water quality variations.

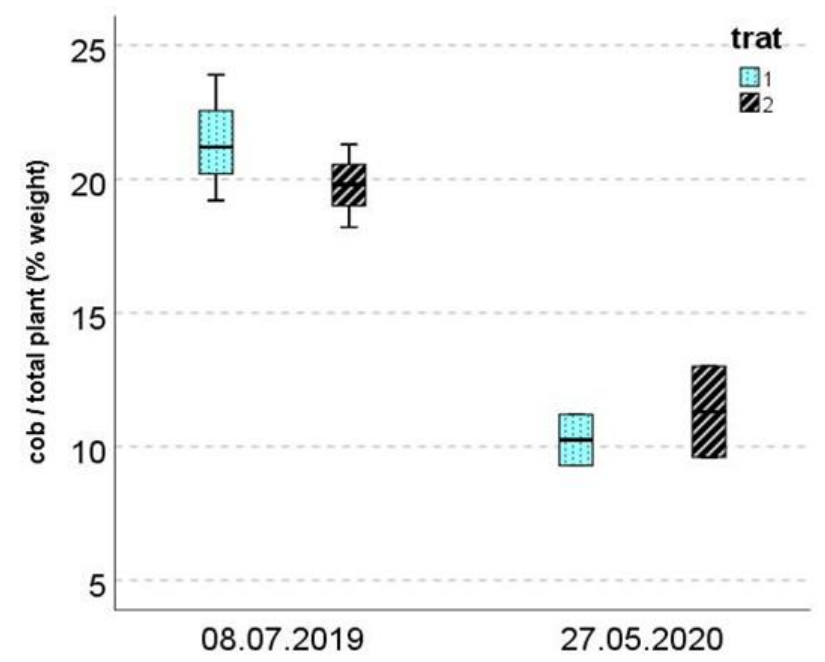

Figure 4. Ratio of cob/total plant weight (in \%), calculated in both 2019 and 2020.

Higher differences were obtained in cob yield by treatment (T1: 10,230 kg/ha vs. T2: $6904 \mathrm{~kg} / \mathrm{ha}$ in 2019 and T1: $5289 \mathrm{~kg} / \mathrm{ha}$ vs. T2: $4867 \mathrm{~kg} / \mathrm{ha}$ in 2020) than that observed in fresh mater. Thus, 33\% higher cob yields were weighed in T1 vs. T2 in 2019 compared to a $14 \%$ increment in fresh matter. This fact must be taken into account when calculating water use efficiency.

Treatment $\bullet$ cob quality interaction was not significant. This result means that the pest damage was not affected by the quantity of water applied (treatment), and therefore, was from the plant water status. This result can be clearly seen if cob quality is expressed in \% weight of each class with respect to the total weigh for each treatment and date (Figure 5).

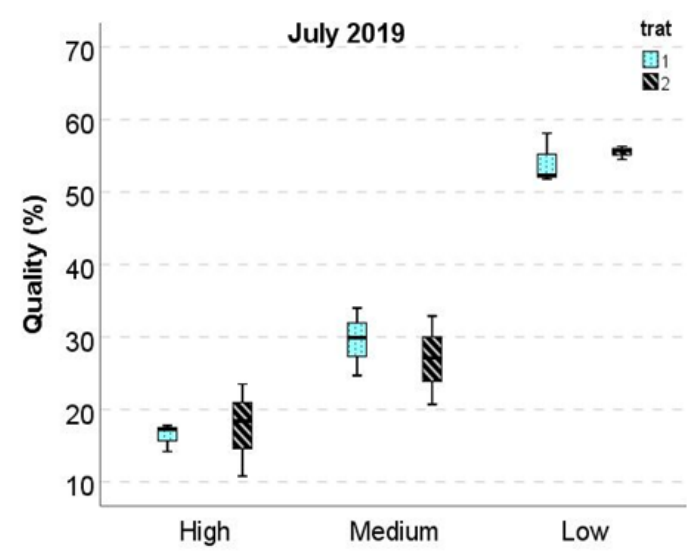

(a)

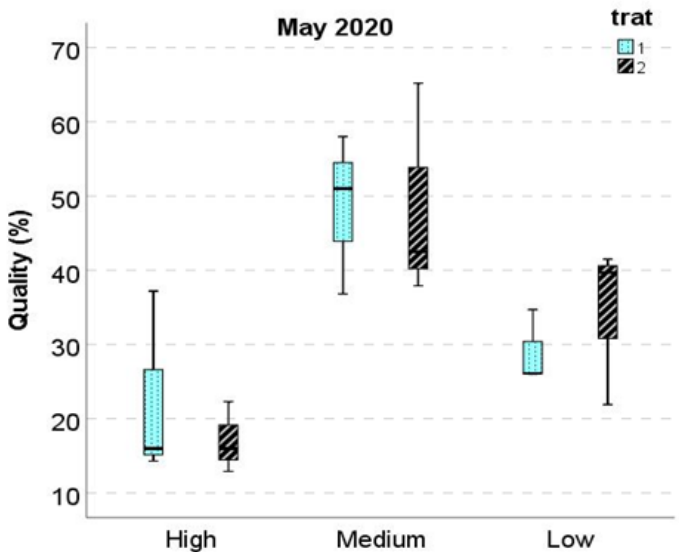

(b)

Figure 5. Box plot of cob quality expressed in \% weight of each class respect to total weigh for each treatment and date (treatment $\bullet$ cob quality interaction was not significant). (a): data from the first harvest (2019) and (b): data from the second harvest (2020). 
Differences between medium and low quality obtained in 2019 and 2020 can be due to the fact that it is a quality classification (not a quantity one), and therefore is not affected by the human criteria applied. Figure 5 also shows the severity of the mentioned pest damage, as less than $20 \%$ of cobs reached the highest quality. Without a proper integrated pest control, able to decrease the mentioned damages, it is not possible to produce Zea mays in a profitable condition. Further studies must be conducted to solve this problem.

The water consumption coefficients for the whole plant were much more favorable in 2019 than in 2020 (329 and 295 L/kg DM, respectively, for T1 and T2 treatments in 2019, as compared to 742 and $687 \mathrm{~L} / \mathrm{kg} \mathrm{DM}$ in 2020). This fact contributes to the high water use efficiency (WUE) obtained in 2019, which was calculated using the ratio of dry mass per area $\mathrm{kg} / \mathrm{ha}$ ) and the amount of water consumed $(\mathrm{mm})$, whose values were 3.04; 3.39; 1.35 and 1.46 (expressed in g/L) for T1 and T2 in 2019 and in 2020, respectively. This result coincides with that pointed out in Reference [27], who mentioned the importance of attaining a relatively high yield for attaining high WUE.

Water consumption coefficients were similar to those calculated in Reference [28] for the second and first cut of maralfalfa (a perennial C4 grass) SDI irrigated, but lower than that obtained for the third cut (once the plant is established and with very supportive temperatures for this crop). Therefore, in terms of water consumption when recollecting the whole plant, it seems that it is more favorable to cultivate perennial species in which plants are not forced to produce a new root system each harvest. In the experiment mentioned above, T1 (more water dosage) presented higher water consumption than T2, as occurred in our Zea mays plot. Consequently, regarding water optimization, it is possible to reduce the water estimated by ETc by using a SDI system (practically all the water supplied is absorbed by the plant) and a precision water management (low dose twice daily). This result is consistent with that pointed out in Reference [29], who hypothesize that, by evaluating drought and wet stresses at different depths, it is possible to identify the critical layer or depth for crop growth, creating knowledge that can be applied to fields with suboptimal water conditions, and may enhance yield, supporting precise stress control management, and boosting crop yield and quality. Other authors [30] measured the soildirect evaporation from the wet bulb for surface drip-irrigated olive orchards, estimating that evaporation represented a fraction of seasonal orchard evapotranspiration, ranging from $4 \%$ to $43 \%$, depending mainly on the fraction of soil surface wetted. In this way, using SDI and a proper water management, non-consumptive water can be eliminated, increasing WUE.

In the same sense, Reference [31] demonstrated that WUE of the maize showed a clear variation due to the installation of drip irrigation, which was an effective method to reduce irrigation water use and to increase crop WUE in arid regions. Additionally, Reference [32] demonstrated that irrigation water use for corn can be reduced by $35 \%-55 \%$ when using SDI compared to more traditional forms of irrigation in the region. They also concluded that irrigation frequency has not been a critical issue when SDI is used for corn production on the deep silt loam soils of the region, so more studies must be conducted to check if this can also happen in Cape Verde conditions.

In the curvilinear relationship, WUE vs. grain yield of bread and durum wheat (C3 cereal) calculated by Reference [27], a maximum value of $1.5 \mathrm{~g} / \mathrm{L}(15 \mathrm{~kg} / \mathrm{ha}-\mathrm{mm})$ was obtained, indicating an offset of WUE at higher grain yields. In the present experiment, 2.41, $2.12 \mathrm{~g} / \mathrm{L}$ of cob yields for T1 and T2 in 2019, respectively, were obtained, higher than mentioned in the maximum for $\mathrm{C} 3$ production. The more effective plant physiology presented by C4 vs. C3 explains this result. Therefore, it is necessary to conduct further experiments to calculate the curvilinear relationship of WUE vs. grain yield of Zea mays in West Africa agro-ecological context to properly optimize water use. Lower than can be expected for a C4 irrigated plant, 0.76 and $0.77 \mathrm{~g} / \mathrm{L}$ were obtained in 2020, consistent with the water shortage coinciding with the cereal critical period. Nonetheless, higher cob yields were obtained in this experimental plot $(10230,6904,5289$ and $4867 \mathrm{~kg} / \mathrm{ha}$, from T1 and T2 of 2019 and 2020, respectively) than is mentioned in Cape Verde statistics, with a 
mean yield of about $2000 \mathrm{~kg} / \mathrm{ha}$ [8] in rain fed conditions. Similar results were found in Reference [33], where a maximum yield of $2.05 \mathrm{t} / \mathrm{ha}$ in Zea mays was obtained, using SDI applying $100 \%$ ET, but a maximum crop water use efficiency (CWUE) under $75 \%$ ET with a value of $0.732 \mathrm{~g} / \mathrm{L}(7.32 \mathrm{~kg} / \mathrm{ha}-\mathrm{mm})$, close to that obtained in 2020 in this experiment. This result shows the potential benefit of the proposed solution to increase food production in West African arid countries if the pest attack is controlled.

Our results point out various facts: the great effect of the pest attack on reducing grain yield, the low plant density used in 2019, useful in rain fed conditions, but which needs to be increased to produce more effectively when irrigated, the great consequence of the irrigation system failure due to the power outage coinciding with filling grain in 2020, the differences in the optimum water dosage regarding the type of yield considered: whole plant (T1 WUE < T2 WUE in 2019) vs. grain (T1 WUE > T2 WUE in 2019) and, finally, the chance to obtain high grain yields derived from the genetic potential of the traditional variety chosen, although frequently used in rain-fed conditions.

Further studies must also be conducted to determine quadratic functions of grain yield vs. the total applied water and used to estimate the levels of irrigation water for maximizing the yield produced by local varieties, net profit and levels to which the crops could be under-irrigated, without reducing income below that which would be earned for full drip irrigation under limited water resources.

\subsection{Plant Characterization: Minerals}

Table 4 presents the contents of minerals in plant leaves and stems. Similar contents were determined in the lab between treatments, with plants showing adequate contents for all the micronutrients. Therefore, the nutrients provided by treated water can save fertilization cost.

Table 4. Contents of minerals (macro and micro, in $\%$ and $\mathrm{mg} / \mathrm{kg}$ of dry matter) in leaves and stems for both irrigating treatments.

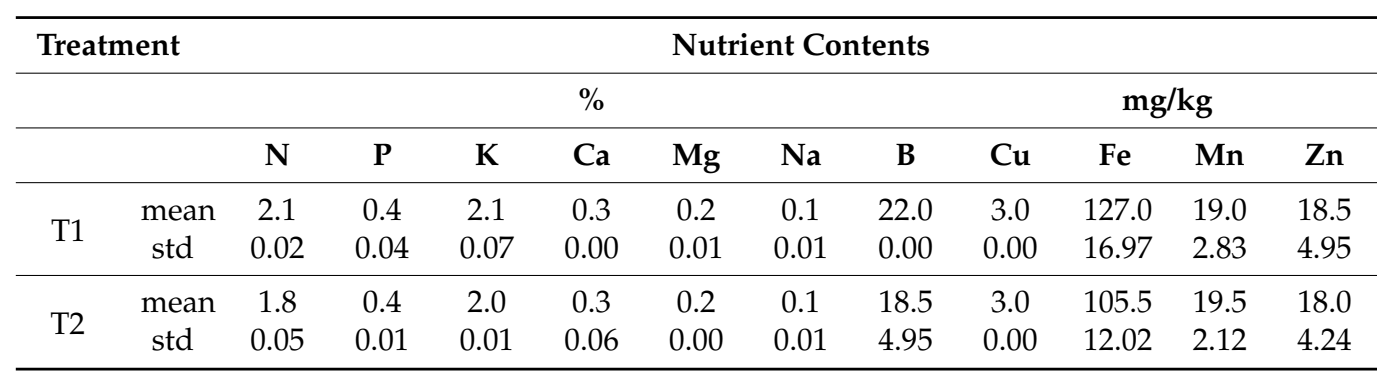

An estimation of $\mathrm{N}$ absorption in 2019 from 200 to 270 can be done (multiplying $\mathrm{N}$ content from Table 4 by an estimation of dry matter yield). Similarly, by using Table 1 and the water applied, the amount of Nitrate added by the treated water can be approximately calculated from 170 and $220 \mathrm{~kg} / \mathrm{ha}$. Therefore, there is an equilibrium (slightly deficit) between soluble $\mathrm{N}$ added by treated water and absorbed by plants, which is consistent with the soil evolution described in 3.2 (soil nitrate values at harvest time similar in irrigated and no irrigated plots). More studies must be conducted to give more precise calculations, due to the environmental importance of this fact.

\section{Conclusions}

Our pilot project demonstrates that safe and profitable water reuse for food production is possible by using the water quality produced by Cape Verde water treatment plants and avoiding water and plant contact by using SDI to decrease sanitary risk.

In order to achieve this challenge, it is necessary to adapt the current agronomical production technologies to the new system (higher plant density, proper mechanization, irrigation system maintenance, controllers to optimize water use, etc.). 
These changes make it necessary to provide guidance to farmers on water-saving cultivation systems and on how to achieve proper maintenance of the irrigation system among others, to ensure sustainable water resources management and agriculture development in water-limited regions.

Further studies must be done to properly determine aspects such as: how to avoid the unsustainable increment of top soil salinity as SDI does not let us lixiviate the top soil, how to apply properly an integrated pest control to avoid Spodoptera frugiperda damages, calculate quadratic functions of grain yield vs. the total applied water (used to estimate the levels of irrigation water for maximizing yield produced by local varieties, net profit and levels to which the crops could be under-irrigated), provide information to properly calculate $\mathrm{N}$ cycle, due to the environmental importance of this nutrient and to optimize the fertilization programs when using treated water.

Our study points out the importance of installation failures (it is necessary to have proper maintenance of water treatment installations) because water shortages can compromise farmers' profitability. Additionally, having storage ponds will lead to a decrease in the mentioned risks and water-quality variations, although suspended solids will increase (a sand filter and a proper irrigation maintenance program are always necessary).

This paper takes into consideration the technical and environmental implications of water reuse in Cape Verde, demonstrating the potential for sustainable waster reuse if the mentioned challenges are addressed.

Supplementary Materials: The following are available online at https:/ /www.mdpi.com/2073-44 41/13/2/160/s1, Figure S1: Left: Water treatment plant, experimental field and mature lagoon (A, above) and (B, below): lay out of the experimental plot in July 2019, including subsurface drip irrigation $\left(360 \mathrm{~m}^{2}, \mathrm{~T} 1\right.$ and $\left.\mathrm{T} 2\right)$, support irrigation $\left(60 \mathrm{~m}^{2}, \mathrm{~T} 3\right)$ and rainfed $\left(60 \mathrm{~m}^{2}, \mathrm{~T} 4\right)$ areas. Drip irrigation area was divided in three blocks in which both of the two irrigated treatments were installed ( 6 subplots of 8 lines of $10 \mathrm{~m}$ long). Observe trees growing close to the T3 and T4 areas. Right: experimental field at the time in which drip lines are being buried. Note soil sensors placed at the topsoil at this time, Figure S2: Pump, filters and fertigation tank from the irrigation head, Figure S3: Plants just before and after the power outage of 14 days in which plants were not irrigated, Figure S4: Spodoptera frugiperda attack causing important losses in plant leaves (left) and in cobs (center). Right: Cobs classification at field in three qualities: high (center, below), poor/moderate (center above) and low pest attack, respectively.

Author Contributions: M.d.P.P.-D. and V.M.-G. had the original idea for the study. V.M.-G., M.d.P.P.-D., A.S.-V. and G.D.S. were responsible for data collection in the field. A.S.-V. was responsible of irrigation system maintenance. J.R.F.-V. and V.M.-G. were responsible for carried out the analyses, while M.d.P.P.-D. and V.M.-G., were responsible for data cleaning and analysis. V.M.-G. and M.d.P.P.-D. drafted the manuscript, which was revised by all authors. All authors read and approved the final manuscript.

Funding: This research was funded by Interreg MAC 2104-2020 Program ADAPTaRES Proyect (MAC/3.5b/102) http://adaptares.com/es/.

Institutional Review Board Statement: Not applicable.

Informed Consent Statement: Not applicable.

Data Availability Statement: The data presented in this study are available on request from the corresponding author.

Acknowledgments: We also appreciate the cooperation: Laboratorio Agroalimentario del Cabildo de Gran Canaria, SISTEMA INGENIERIA and INIDA.

Conflicts of Interest: The authors declare no conflict of interest.

\section{References}

1. World Bank. Data. 2020. Available online: https://data.worldbank.org/country/cabo-verde (accessed on 25 July 2020).

2. Duarte, M.C.; Romeiras, M.M. Cape Verde Islands, Encyclopedia of Islands; University of California Press: Oakland, CA, USA, 2009; Available online: https://www.researchgate.net/publication/231168292_Cape_Verde_Islands (accessed on 25 July 2020). 
3. Monteiro, F.; Fortes, A.; Ferreira, V.; Pereira Essoh, A.; Gomes, I.; Correia, A.M.; Romeiras, M.M. Current Status and Trends in Cabo Verde Agriculture. Agronomy 2020, 10, 74.

4. World Bank Group. Climate Change Knowledge Portal. Available online: https://climateknowledgeportal.worldbank.org/cou ntry/cape-verde/climate-sector-agriculture (accessed on 8 August 2020).

5. Available online: https://www.ifad.org/en/web/operations/country/id/cape_verde (accessed on 2 July 2020).

6. Food and Agriculture Organization of the United Nations (FAO). AQUASTAT Main Database-AQUASTAT, FAO's Global Information System on Water and Agriculture. 2016. Available online: http://www.fao.org/nr/aquastat (accessed on 8 August 2020).

7. Instituto Nacional de Estatística. Praia, Cape Verde, 2018. Estatisticas do Ambiente 2016. Available online: http://ine.cv/wp-co ntent/uploads/2018/06/estatisticas-do-ambiente-2016.pdf (accessed on 20 July 2020).

8. AQUASTAT-Calendarios de Cultivos Regados. Organización de las Naciones Unidas Para la Alimentación y la Agricultura. Available online: http://www.fao.org/aquastat/en/data-analysis/irrig-water-use/irrigated-crop-calendars (accessed on 20 July 2020).

9. AQUASTAT. Available online: http://www.fao.org/nr/water/aquastat/data/query/results.html (accessed on 20 July 2020).

10. Proença de Oliveira, R.; Nascimento, J.; Simões, J. Balanço hidrológico e estimativas da disponibilidade de água Ilha de Santiago. 2017. R1.1 at em recursos hídricos. Available online: https://d1wqtxts1xzle7.cloudfront.net/53503696/Balanco_Hidrico_Santiag o2017.pdf?1497439171=\&response-content-disposition=inline\%3B+filename\%3DASSISTENCIA_TECNICA_AS_INSTITUIC OES_NACI.pdf\&Expires=1610424554\&Signature=b8035qQHTb8u \{\}uvlHolAh7ejGZClB5rXnml1uQClbB4SkpJKSnMfs6EXD5 ukT2GMS9bFsAuQrmdhHOyNwKt787MJA93aidz8qvlLKGmRzfAlu0aFFGrg1OD3qofGqiO6RfToEfWN4O3clfVFAntMPzbP k48k \{\}JLoq9yV4FE47S-RjKZ9WzN1JLB6fohGIK7sVHtswmP4ym8IbIB5nx5CryO2T4b7rLS8OUPfdJttO5RExgcvDq9mrRWn SA1Bzgp8 \{\}LRqL9htZzaIVQS1yRlX8jUdnaC9bFXpa5ardOg16vbu4o5b7 \{\}Fx0r2OnxOLvpiW8GJqZcEsQ4of3zE7tc44Rw_\& Key-Pair-Id=APKAJLOHF5GGSLRBV4ZA (accessed on 2 July 2020).

11. SDG Cabo Verde. Voluntary National Report on the Implementation of the 2030 Agenda for Sustainable Development. 2018. Available online: https://sustainabledevelopment.un.org/content/documents/19580Cabo_Verde_VNR_SDG_Cabo_Verde_2 018_ING_final_NU_280618.pdf (accessed on 11 June 2020).

12. Mendoza-Grimón, V.; Fernández-Vera, J.R.; Hernández-Moreno, J.M.; Palacios-Díaz, M.P. Sustainable Irrigation Using NonConventional Resources: What has Happened after 30 Years Regarding Boron Phytotoxicity? Water 2019, 11, 1952. [CrossRef]

13. Hedleya, C.B.; Roudiera, P.; Yuleb, I.J.; Ekanayakea, J.; Bradbury, S. Soil water status and water table depth modelling using electromagnetic surveys for precision irrigation scheduling. Geoderma 2013, 199, 22-29. [CrossRef]

14. Mendoza-Grimon, V. Reutilización de Aguas Depuradas Para el Riego Localizado de Especies Forrajeras: El Ciclo del Fósforo en el Medio Ambiente Rural. Ph.D. Thesis, Universidad de Las Palmas de Gran Canaria, Las palmas de Gran Canaria, Spain, 2005. Available online: http:/ / hdl.handle.net/10553/21208 (accessed on 20 May 2020).

15. Winpenny, J.; Heinz, I.; Koo-Oshima, S. Reutilización del Agua en Agricultura: Beneficios Para Todos? FAO Informe sobre Temas hídricos: Rome, Italy, 2013; p. 35.

16. Camp, R.C. Subsurface drip irrigation: A review. Trans. ASAE 1998, 41, 1353-1367.

17. Palacios, M.P.; Mendoza-Grimón, V.; Fernández, F.; Fernández-Vera, J.R.; Hernández-Moreno, J.M. Sustainable Reclaimed Water Management by Subsurface Drip Irrigation System: A study case for forage production. Water Pract. Technol. 2008, 3. [CrossRef]

18. Estação de Tratamento de Águas Residuais "ETAR" Cabo Verde Estudo e Caracterização; Agência Nacional de Água e Saneamento "ANAS": Praia, Cabo Verde, 2016.

19. Abrahams, P.; Beale, T.; Cock, M.; Corniani, N.; Day, R.; Godwin, J.; Vos, J. Fall Armyworm Status. Impacts and control options in Africa: Preliminary Evidence Note April 2017. Available online: https:/ /www.cabi.org/Uploads/isc/Dfid\%20Faw\%20Inception \%20Report04may2017final.pdf (accessed on 2 July 2020).

20. Day, R.; Abrahams, P.; Bateman, M.; Beale, T.; Clottey, V.; Cock, M.; Witt, A. Fall armyworm: Impacts and implications for Africa. Outlooks Pest Manag. 2017, 28, 196-201. [CrossRef]

21. Smith, M. CROPWAT: A Computer Program for Irrigation Planning and Management; Food and Agriculture Organization of the United Nations, Ed.; FAO irrigation and drainage paper 46; Food and Agriculture Organization of the United Nations: Rome, Italy, 1992; ISBN 9251031061. Available online: http:/ / www.fao.org/land-water/databases-and-software/cropwat/es/ (accessed on 2 February 2019).

22. Delta-T Devices. User Manual for the SM300 Soil Moisture Sensor, SM300-UM-1.1; Delta-T Devices: Cambridge, UK, 2010.

23. Olsen, S.R.; Sommers, L.E. Phosphorus. In Methods of Soil Analysis. Part 2. Chemical and Microbiological Properties, Agronomy Monograph 9.2; Miller, R.H., Keeney, E.R., Eds.; America Society Agronomy, Inc.: Madison, WI, USA; Soil Science of America, Inc.: Madison, WI, USA, 1982; pp. 1035-1049.

24. AQUASTAT Climate-Information Tool. Available online: http://www.fao.org/aquastat/en/geospatial-information/climate-inf ormation (accessed on 20 July 2020).

25. Palacios-Díaz, M.P.; Mendoza, V.; Fernández-Vera, J.R.; Rodríguez, F.; Tejedor-Junco, M.T.; Hernández-Moreno, J.M. Subsurface drip irrigation and reclaimed water quality effects on phosphorus and salinity distribution and forage production. Agric. Water Manag. 2009, 96, 1659-1666. [CrossRef]

26. Freddie, R.; Lamm, C.; Camp, R. Subsurface Drip Irrigation. Dev. Agric. Eng. 2007, 13, 473-551.

27. Zhang, H.; Oweis, T. Water-yield relations and optimal irrigation scheduling of wheat in the Mediterranean region. Agric. Water Manag. 1999, 38, 195-211. [CrossRef] 
28. Improving Water Use in Fodder Production. Available online: https://www.researchgate.net/publication/277968022_Improving _Water_Use_in_Fodder_Production (accessed on 11 August 2020).

29. Hamada, K.; Inoue, H.; Mochizuki, H.; Asakura, M.; Shimizu, Y.; Takemura, T. Evaluating Maize Drought and Wet Stress in a Converted Japanese Paddy Field Using a SWAP Model. Water 2020, 12, 1363. [CrossRef]

30. Bonachela, S.; Orgaz, F.O.; Villalobos, F.J.; Fereres, E. Soil evaporation from drip-irrigated olive orchards. Irrig. Sci. 2001, 20, 65-71. [CrossRef]

31. Wang, H.; Li, X.; Tan, J. Interannual Variations of Evapotranspiration and Water Use Efficiency over an Oasis Cropland in Arid Regions of North-Western China. Water 2020, 12, 1239. [CrossRef]

32. Lamm, F.R.; Trooien, T.P. Subsurface drip irrigation for corn production: A review of 10 years of research in Kansas. Irrig. Sci. 2003, 22, 195-200. [CrossRef]

33. Gupta, A.; Rao, K.V.R.; Singh, S.; Soni, K.; Sawant, C. Water productivity and yield of baby corn (Zea mays L.) as influenced by irrigation levels under subsurface drip irrigation. Int. J. Chem. Stud. 2019, 7, 128-135. 